\title{
PENGARUH KONSEP DIRI DAN KECEMASAN SISWA TERHADAP PEMAHAMAN KONSEP MATEMATIKA
}

\author{
SHINTA DWI HANDAYANI \\ Shintadwi_1109@yahoo.com \\ Program Studi Teknik Informatika, Fakultas Teknik, Matematika, dan IPA \\ Universitas Indraprasta PGRI
}

\begin{abstract}
Abstrak. Penelitian ini dilakukan dengan tujuan mengetahui pengaruh konsep diri dan kecemasan siswa terhadap pemahaman konsep matematika. Populasi terjangkau adalah siswa siswi kelas XI IPS tahun ajaran 2014/2015 swasta di kota Depok. Besar sample sebanyak 90 siswa, dengan teknik sampling yang digunakan adalah teknik gabungan antara proporsional dan random, di ambil dari 3 sekolah swasta. Instrumen penelitian yang digunakan yaitu angket konsep diri sebanyak 37 pernyataan, angket kecemasan siswa sebanyak 36 pernyataan, tes pemahaman konsep matematika berbentuk pilihan ganda sebanyak 24 soal, yang telah di uji validitasnya. Analisis data menggunakan analisis jalur. Hasil pengujian hipotesis menunjukan bahwa: 1) Terdapat pengaruh langsung yang signifikan konsep diri terhadap pemahaman konsep matematika. 2) Terdapat pengaruh langsung yang signifikan kecemasan siswa terhadap pemahaman konsep matematia. 3) Terdapat pengaruh langsung yang signifikan konsep diri terhadap kecemasan siswa. 4) Terdapat pengaruh tidak langsung konsep diri terhadap pemahaman konsep matematika melalui kecemasan siswa.
\end{abstract}

Kata kunci: konsep diri, kecemasan siswa, pemahaman konsep matematika.

\begin{abstract}
This research was conducted with the purpose of knowing the self concept and anxiety influence students towards an understanding of mathematical concepts. The methods used in this research is a survey method. Affordable population are students of Class XI Science social sciences academic year 2014/2015 in Depok. Large sample as much as 90 students, with a sampling technique used was a combination of proportional and random, taken from three private schools. Research instrument used, namely the now self concept as much as 37 statement, now as many as 36 students anxiety statements, test understanding math concepts shaped 24 multiple choice question, which has been in test validitasnya. Data analysis using path analysis. The results of hypothesis testing indicate that: 1) there is a significant direct influence on the concept itself against the understanding of mathematical concepts. 2) there is a significant direct influence on anxiety of students towards an understanding of mathematical concepts. 3) there is a significant direct influence on the concept of yourself against anxiety students. 4) there is an indirect influence on the concept of understanding the mathematical concepts themselves against through the anxiety of students.
\end{abstract}

Keywords: self concept, to the dismay of the students, understanding of math concepts.

\section{PENDAHULUAN}

Matematika merupakan ilmu universal yang mempunyai peran penting dalam berbagai disiplin ilmu dan mengembangkan daya pikir manusia. Matematika adalah disiplin ilmu yang telah dipelajarai semenjak pendidikan dasar dan membantu perkembangan disiplin ilmu lain seperti fisika, kimia, biologi, ekomomi, dan lainya. Matematika merupakan disiplin ilmu yang sangat bermanfaat dalam kehidupan sehari hari, dengan belajar metematika seseorang dilatih untuk berpikir kreatif, kritis, jujur dan 
dapat mengaplikasikan ilmu matematika dalam menyelesaikan suatu permasalahan dalam kehidupan sehari-hari maupun dalam disiplin ilmu lainnya. Berdasarkan uraian tersebut jelaslah bahwa matematika merupakan ilmu yang sangat penting, maka hal ini lah yang menjadi salah satu faktor mengapa metematika dijadikan pelajaran wajib disetiap jenjang pendidikan.

Tujuan pembelajaran matematika di sekolah menurut peraturan menteri pendidikan nasional (2006) adalah memahami konsep matematika, menjelaskan keterkaitan antar konsep dan mengaplikasikan konsep secara luwes, akurat, efisien, dan tepat dalam pemecahan masalah. Belajar matematika dengan disertai pemahaman merupakan kompenen terpenting dari kemampuan bersama dengan kecakapan pengetahuan faktual dan prosedural. Belajar matematika dengan disertai pemahaman sangat diperlukan untuk memungkinkan siswa menyelesaikan masalah lain yang akan mereka hadapi di masa yang akan datang.

Namun, pentingnya pemahaman yang telah di jelaskan sebelumnya tidak sejalan dengan kemampuan pemahaman matematis yang telah dicapai siswa saat ini, hal ini terlihat dari hasi belajar matematika disekolah kurang memuaskan semua pihak. Salah satu penyebab kurangnya pemahaman konsep matematika siswa adalah karena masih banyak dari siswa yang menganggap bahwa pelajran matematika adalah pelajaran yang sukar dan biasanya belajar matematika memerlukan konsentrasi tinggi. Saat ini, masih banyak siswa yang mengalami kesulitan belajar matematika. Mereka menganggap matematika suatu pelajaran yang menakutkan, membosankan, dan menjadi beban bagi siswa karena bersifat abstrak, penuh dengan angka dan rumus. Hal ini sejalan dengan Ruseffendi (2006: 156) yang mengemukkan bahwa terdapat banyak peserta didik yang setelah belajar matematika, tidak mampu memahami bahkan pada bagian yang apling sederhana sekalipun, banyak konsep yang dipahami secara keliru sehingga matematika dianggap sebagai ilmu yang sukar, ruwet, dan sulit.

Ketidakmampuan pemahaman konsep matematika inilah yang menimbulkan kecemasan siswa pada saat pelajaran matematika. Ashcraft dalam Anita (2014:97) mendefinisikan kecemasan matematika sebagai perasaan ketegangan, cemas atau ketakutan yang mengganggu kinerja matematika. Siswa yang mengalami kecemasan matematika cenderung menghindari situasi dimana mereka harus mempelajari dan mengerjakan matematika. Kecemasan yang dialami siswa pada mata pelajaran matematika sering disebut sebagai kecemasan matematika (Mathematics Anxiety). Kecemasan terhadap matematika tidak bisa dipandang sebagai hal biasa, karena ketidak mampuan siswa dalam beradaptasi pada pelajaran menyebabkan siswa kesulitan serta fobia terhadap matematika yang akhirnya menyebabkan hasil belajar dan prestasi siswa dalam matematika rendah.

Namun tanggapan individu yang sehat terhadap diri dan kehidupannya merupakan landasan dasar untuk dapat menyesuaikan diri. Faktor konsep diri perlu juga dipertimbangkan dalam menentukan berhasil tidaknya penyesuaian diri seseorang. Dengan kata lain konsep diri merupakan hal yang sangat mempengaruhi penyesuaian diri dan merupakan faktor penting dalam perkembangan diri seseorang.

Bila seseorang yakin bahwa orang-orang yang penting baginya menyenangi mereka, maka mereka akan berpikir positif tentang diri mereka dan orang yang memiliki konsep diri positif berarti memiliki penerimaan diri dan harga diri yang positif. Mereka menganggap dirinya barharga dan cenderung menerima diri sendiri sebagaimana adanya. Sebaliknya, orang yang memiliki konsep diri negatif, menunjukkan penerimaan diri yang negatif pula. Mereka memiliki perasaan kurang berharga, yang menyebabkan perasaan benci atau penolakan terhadap diri sendiri. seseorang yang mempunyai konsep diri positif 
akan membantu dalam mengerjakan tugas dan sebaliknya remaja dengan konsep diri negatif akan menghambat dalam menyelesaikan tugasnya.

Sejauh mana keberhasilan seseorang dalam penyesuaian diri dengan lingkungan, maka akan dipengaruhi oleh beberapa faktor antara lain kepribadian orang tersebut. Seperti halnya perkembangan dan pertumbuhan manusia yang mencakup berbagai fungsi fisik dan mental, maka kepribadian seseorang juga memiliki perkembangan dan perubahan. Berdasarkan paparan di atas, maka penulis merasa perlu untuk meneliti dengan tujuan untuk menemukan secara empiris tentang pengaruh variabel konsep diri dan kecemasan siswa terhadap pemahaman konsep matematika.

\section{TINJAUAN PUSTAKA}

\section{Pemahaman Konsep Matematika}

Pemahaman konsep adalah kemampuan individu untuk memahami suatu konsep tertentu. Seorang siswa telah memiliki pemahaman konsep apabila siswa telah menangkap makna atau arti dari suatu konsep. Bentuk dari pemahaman konsep berupa pemahaman terjemahan, pemahaman penafsiran dan pemahaman Ekstrapolasi.

Menurut Sumarmo dalam Kesumawati (2008:231) pemahaman diartikan dari kata Understanding. Derajat pemahaman ditentukan oleh tingkat keterkaitan suatu gagasan, prosedur atau fakta matematika dipahami secara menyeluruh jika hal-hal tersebut membentuk jaringan dengan keterkaitan yang tinggi dan konsep diartikan sebagai ide abstrak yang dapat digunakan untuk menggolongkan sekumpulan objek. Pemahaman konsep merupakan bagian yang penting yang harus dimiliki oleh anak untuk berpikir dalam menyelesaikan berbagai permasalahannya baik itu mengenai pelajaran maupun kehidupan sehari-hari.

Menurut Hamalik (2008:166) untuk mengetahui apakah siswa telah mengetahui dan memahami suatu konsep, paling tidak ada 4 hal yang telah diperbuatnya yaitu sebagai berikut: 1) ia dapat menyebutkan nama contoh-contoh konsep bila dia melihatnya, 2) ia dapat menyatakan ciri-ciri konsep itu, 3) ia dapat memilih, membedakan antara contohcontoh dari yang bukan contoh, 4) ia mungkin lebih mampu memecahkan yang berkenaan dengan konsep.

Sementara menurut Skemp dan Pollatsek dalam Kesumawati (2008:231) yang menyatakan bahwa: Terdapat dua jenis pemahaman konsep, yaitu pemahaman instrumental dan pemahaman rasional. Pemahaman instrumental dapat diartikan sebagai pemahaman atas konsep yang saling terpisah dan hanya rumus yang dihafal dalam melakukan perhitungan sederhana, sedangkan pemahaman rasional termuat satu skema atau strukstur yang dapat digunakan pada penyelesaian masalah yang lebih luas. Suatu ide, fakta, atau prosedur matematika dapat dipahami sepenuhnya jika dikaitkan dengan jaringan dari sejumlah kekuatan koneksi.

Menurut Dimyati (2009:1) “ Belajar matematika adalah belajar non fisik, dengan belajar metematika pola pikir ketajaman akal dan sistematika di otak kita semua terasah dan terlatih". Berdasarkan pendapat Dimyati dapat dikatakan bahwa matematika adalah suatu cara untuk menemukan suatu jawaban terhadap masalah yang dihadapi manusia, karena matematika ada dimana-mana disekitar kita didalam berbagai kegiatan kita seharihari. Sementara menurut Soedjadi dalam Heruman (2010:1): "Matematika adalah memiliki objek tujuan abstrak, bertumpu pada kesepakatan dan pola pikir yang deduktif". Pola pikir yang deduktif adalah pola pikir yang deduksi. Deduksi adalah penarikan kesimpulan dari keadaan yang umum ke keadaan yang khusus. Sehinggga matematika merupakan pelajaran yang memiliki objek tujuan yang tidak terbentuk hanya bertumpu pada kesepakatan dan pola pikir yang deduktif atau pola pikir yang umum. 
Berdasarkan uraian yang dikemukakan diatas penulis menarik kesimpulan, Pemahaman konsep matematika adalah salah satu kecakapan atau kemahiran matematika yang diharapkan dapat tercapai dalam belajar matematika yaitu dengan menunjukkan pemahaman konsep matematika yang dipelajarinya, menjelaskan keterkaitan antar konsep dan mengaplikasikan konsep atau algoritma secara luwes, akurat, efisien, dan tepat dalam pemecahan masalah.

\section{Konsep Diri}

Dalam kamus besar bahasa Indonesia istilah "konsep" memiliki arti gambaran, proses atau hal-hal yang digunakan oleh akal budi untuk memahami sesuatu. Istilah "diri" berarti bagian-bagian dari individu yang terpisah dari yang lain. Konsep diri dapat diartikan sebagai gambaran seseorang mengenai dirinya sendiri atau penilaian terhadap dirinya sendiri. Sama halnya dengan Slameto (2010:182) menyatakan bahwa: "Konsep diri adalah persepsi keseluruhan yang dimiliki seseorang mengenai dirinya sendiri".

Mulyana (2000:7) menyatakan: "konsep diri adalah pandangan individu mengenai siapa diri individu, dan itu bisa diperoleh lewat informasi yang diberikan lewat informasi yang diberikan orang lain pada diri individu". Hal ini sejalan dengan Tanamal (2004:124) yang berpendapat bahwa: "Konsep diri adalah cara individu melihat gambaran diri sendiri yang terbentuk berdasarkan pemikiran-pemikiran individu dari interaksinya dengan orang lain". Konsep diri adalah evaluasi individu mengenai diri sendiri, penilaian atau penaksiran mengenai diri sendiri oleh individu yang bersangkutan (Chaplain, 2001:203).

Sementara menurut Mead dalam Slameto (2010:182) menyatakan: "konsep diri sebagai suatu produk sosial yang dibentuk melalui proses internalisasi dan organisasi pengalaman-pengalaman psikologis". Pengalaman-pengalaman psikologis ini merupakan hasil eksplorasi individu terhadap lingkungan fisiknya dan refleksi dari dirinya sendiri yang diterima dari orang-orang yang berpengaruh pada dirinya. Masih dalam buku yang sama Burns (2010:182) menyatakan: "the self concept refers to the connection of attitudes and beliefs we houldabout ourselves". Konsep ini merupakan suatu kepercayaan mengenai keadaan diri sendiri yang relatif sulit diubah. Konsep diri tumbuh dari interaksi seseorang dengan orang-orang lain yang berpengaruh dalam kehidupannya, biasanya orang tua, guru, dan teman-teman.

Fitts dalam Respati (2006: 122-123) melihat bahwa pengamatan seseorang terhadap dirinya dapat dilihat dari dua dimensi yaitu dimensi internal dan dimensi eksternal. Pada dimensi internal, individu melihat dirinya sebagai suatu kesatuan unik dan dinamis ketika ia melakukan pengamatan dan penilaian terhadap identitas dirinya, tingkah lakunya dan kepuasan dirinya. Sedangkan dimensi eksternal adalah pengamatan dan penilaian terhadap diri yang timbul ketika individu berinteraksi dengan dunia luar, khususnya hubungan interpersonal. Kedua dimensi ini beserta bagian-bagian diri yang ada saling berhubungan membentuk suatu kepribadian.

Berdasarkan uraian yang dikemukakan diatas penulis menarik kesimpulan, konsep diri adalah pandangan perasaan yang dimiliki siswa mengenai dirinya sendiri yang di dapat dari proses pengamatan terhadap diri sendiri maupun menurut persepsi orang lain berupa karakteristik fisik, pasikologi dan sosial.

\section{Kecemasan Siswa}

Salah satu bentuk perasaan seorang siswa ketika menghadapi ujian khususnya ujian matematika adalah terjadinya perasaan tidak mengenakkan atau merasa takut dan tegang. Beberapa siswa kadang menyikapi ujian sebagai suatu permasalahan dalam hidupnya, baik karena nantinya ia akan malu karena tidak mendapat nilai yang bagus maupun karena merasa tidak percaya diri dengan persiapan yang dimilikinya. 
Perasaan takut atau tegang dalam menghadapi suatu persoalan tersebut disebut kecemasan. Crow dan Crow dalam Wicaksono dan Saufi (2013:90) mengemukakan bahwa: "kecemasan adalah sesuatu kondisi kurang menyenangkan yang dialami oleh individu yang dapat mempengaruhi keadaan fisiknya". Senada dengan yang dikemukakan oleh Crow dan Crow, menurut Soehardjono dalam Wicaksono dan Saufi (2013:91): "kecemasan adalah manifestasi dari gejala-gejala atau gangguan fisiologi seperti: gemetar, banyak keringat, mual, sakit kepala, sering buang air, palpitasi (debaran atau berdebar-debar)".

Menurut Rathus dalam Nawangsari (2001:83): "kecemasan didefinisikan sebagai keadaan psikologis yang ditandai oleh adanya tekanan, ketakutan, kegalauan dan ancaman yang berasal dari lingkungan”. Sementara itu menurut Zakiyah Derajat dalam Wicaksono dan Saufi (2013:90), "kecemasan adalah manifestasi dari berbagai proses emosi yang bercampur aduk, yang terjadi ketika individu sedang mengalami tekanan perasaan atau frustasi dan pertentangan batin atau konflik". Sedangkan menurut Nawangsari (2001:83), "kecemasan adalah suatu kondisi yang tidak menyenangkan meliputi rasa takut, rasa tegang, khawatir, bingung, tidak suka yang sifatnya subjektif dan timbul karena adanya perasaan tidak aman terhadap bahaya yang diduga akan terjadi". Gejala kecemasan ada dalam bermacam-macam bentuk dan kompleksitasnya, namun biasanya cukup mudah dikenali. Seseorang yang mengalami kecemasan cenderung untuk terus menerus merasa khawatir akan keadaan yang buruk yang akan menimpa dirinya atau diri orang lain yang dikenalnya dengan baik.

Wicaksono dan Saufi (2013:93) menyatakan bahwa: "salah satu sebab utama kecemasan siswa adalah otoritas guru". Perlu diingat bahwa setiap kali skema yang diperlukan dalam pemahaman tidak hadir dan tersedia dalam pikiran siswa, apapun pembelajaran yang terjadi hanya didasarkan atas apa yang siswa terima dari otoritas guru. Belajar dengan cara tersebut adalah rote-learning (hafalan) bukan schematic-learning (secara skema). Pembelajaran tersebut mungkin tidak akan diawali dengan kecemasan siswa. Masalahnya adalah sulit membedakan antara anak yang cerdas dan anak yang mau/bisa menghafal banyak proses dasar matematika dengan baik dibanding berdasarkan pemahaman. Cepat atau lambat akan terjadi kecemasan pada siswa. Hal tersebut dapat terjadi karena dua hal, yaitu: 1) Ilmu matematika yang dipelajari semakin maju dan kompleks yang tidak mungkin dapat dihafalkan dengan memori yang dimiliki siswa. 2) Masalah rutin terbatas pada masalah-masalah tertentu dan tidak dapat diadaptasikan ke masalah lain yang berbeda berdasarkan ide-ide matematika yang sama.

Berdasarkan uraian yang dikemukakan diatas penulis menarik kesimpulan kecemasan siswa adalah perasaan cemas saat seseorang belajar yang timbul karena adanya tekanan dan ketidakmampuan menghadapi masalah. Kecemasan siswa dalam belajar dicirikan dengan kegelisahan, kekhawatiran, ketakutan yang tidak mendasar bahwa akan terjadi hal-hal yang tidak diinginkan.

\section{METODE}

Penelitian ini merupakan penelitian survey dengan pendekatan kuantitatif, dimana peneliti menggambarkan fenomena yang terjadi berdasarkan data yang diambil dari responden menggunakan instrument yang telah divalidasi sebelumnya. Desain penelitian yang digunakan adalah analisis jalur yaitu desain penelitian yang dilakukan jika antara variabel $X_{1}$ dan $X_{2}$ terdapat hubungan atau dengan kata lain terdapat varabel intervening yaitu $\mathrm{X}_{2}$ pada penelitian tersebut.

Desain penelitian ini digunakan untuk mengetahui ada tidaknya pengaruh antara ketiga variabel tersebut secara langsung maupun tidak langsung. Konstelasi masalah penelitian ini sebagai berikut: 


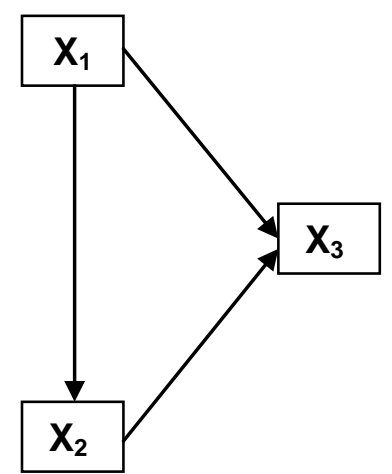

Gambar 1. Konstelasi Masalah

Keterangan:

$\mathrm{X}_{1}$ : Konsep Diri

$\mathrm{X}_{2}$ : Kecemasan Siswa

$\mathrm{X}_{3}$ : Pemahaman Konsep Matematika

\section{HASIL DAN PEMBAHASAN}

\section{Analisis Deskriptif}

Skor konsep diri yang di peroleh dari para responden mempunyai skor terendah 109, skor tertinggi 157, skor rata-rata sebesar 133,71 median sebesar 133,00 modus sebesar 133 dan simpangan baku 12,194, angka simpangan baku sebesar 12,194 atau sama dengan 9,12\% dari rata-rata, menunjukan perbedaan konsep diri antar responden termasuk rendah. Hal ini menunjukan bahwa konsep diri dari responden tidak banyak beragam. Dari deskripsi tersebut juga dapat dilihat bahwa nilai rata-rata dan median hampir sama, yaitu 133,71 dan 133,00. Hal ini menunjukan bahwa konsep diri pada penelitian ini cukup representative.

Skor kecemasan siswa yang di peroleh dari para responden mempunyai skor terendah 101, skor tertinggi 168, skor rata-rata sebesar 137,34 median sebesar 138,00 modus sebesar 138 dan simpangan baku 16,217, angka simpangan baku sebesar 16,217 atau sama dengan $11,81 \%$ dari rata-rata, menunjukan perbedaan kecemasan siswa antar responden termasuk rendah. Hal ini menunjukan bahwa kecemasan siswa dari responden tidak banyak beragam. Dari deskripsi tersebut juga dapat dilihat bahwa nilai rata-rata dan median hampir sama, yaitu 137,34 dan 138,00. Hal ini menunjukan bahwa kecemasan siswa pada penelitian ini cukup representative.

Skor pemahaman konsep matematika yang di peroleh dari para responden mempunyai skor terendah 12 , skor tertinggi 24 , skor rata-rata sebesar 17,87 median sebesar 18 modus sebesar 18 dan simpangan baku 3,051, angka simpangan baku sebesar 3,051 atau sama dengan $17,07 \%$ dari rata-rata, menunjukan perbedaan pemahaman konsep matematika antar responden termasuk rendah. Hal ini menunjukan bahwa pemahaman konsep matematika dari responden tidak banyak beragam. Dari deskripsi tersebut juga dapat dilihat bahwa nilai rata-rata dan median hampir sama, yaitu 17,87 dan 18,00 . Hal ini menunjukan bahwa pemahaman konsep matematika pada penelitian ini cukup representative.

\section{Pengujian Persyaratan Analisis}

Hasil pengujian dengan menggunakan SPSS 20 diperoleh hasil sebagai berikut: variabel konsep diri nila Kolmogorov-Smirnov $Z=0,853$ dengan probabilitas 0,461 (Asymp. Sig. (2-tailed)), variabel kecemasan siswa nila Kolmogorov-Smirnov $Z=0,901$ dengan probabilitas 0,391 (Asymp. Sig.(2-tailed)), dan variabel pemahaman konsep 
matematika nila Kolmogorov-Smirnov $Z=0,692$ dengan probabilitas 0,724 (Asymp. Sig. (2-tailed)).

Menurut ketentuan yang ada pada program SPSS 20 maka criteria dari normalitas adalah "jika $p$ value (sig) $>0,05$ berarti data pada sampel tesebut berdistribusi normal". Dari data yang diperoleh menunjukkan bahwa nilai $p$ value $($ sig) $>0,05$ maka ketiga variabel berdistribusi normal.

Uji linieritas dilakukan untuk mengetahui, membuktikan bahwa hubungan antar variabel yang diteliti memiliki hubungan yang linear. Dalam melakukan uji linear regresi antar variabel, peneliti malakukan analisis regresi dengan bantuan SPSS 20 dengan hasil sebagai berikut: Konsep Diri dengan Pemahaman Konsep Matematika menghasilkan nilai $\mathbf{F}=\mathbf{0 , 9 2 7}$ dengan nilai probabilitas (kolom sig) $\boldsymbol{p}=\mathbf{0 , 5 1 9}$. Kecemasan Siswa dengan Pemahaman Konsep Matematika menghasilkan nilai $\mathbf{F}=\mathbf{1 , 5 8 7}$ dengan nilai probabilitas (kolom sig) $\boldsymbol{p}=\mathbf{0 , 0 9 9}$. Konsep Diri dengan Kecemasan Siswa menghasilkan nilai $\mathbf{F}=$ $\mathbf{1 , 0 8 0}$ dengan nilai probabilitas (kolom sig) $\boldsymbol{p}=\mathbf{0 , 3 8 8}$. Jika nilai probabilitas $p>0,05$ maka artinya model regresi bersifat linear, berdasarkan data yang diperoleh hubungan anatar variabel memiliki nilai $p>0,05$, dengan demikian dapat disimpulkan model regresi bersifat linier.

Berdasarkan pengolahan data dengan SPSS menunjukkan nilai Tolerance 0,479 dimana lebih besar dari 0,10 dan nilai VIF 2,088 lebih kecil dari 10,00. Maka terdapat dugaan bebas dari adanya kolinieritas antara variable konsep diri dengan kecemasan siswa.

\section{Pengujian Hipotesis Penelitian}

Pengujian hubungan antar variabel penelitian menggunakan analisis jalur (Path Analysis).

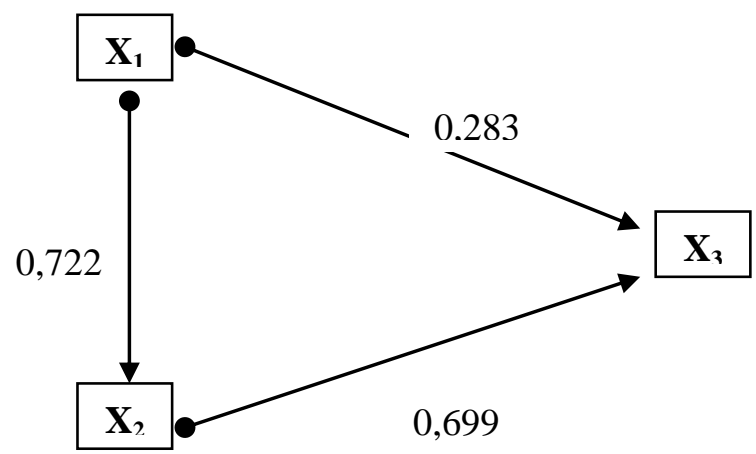

Gambar 2. Hasil Perhitungan Analisis Jalur

\section{Pengujian Hipotesis 1}

Nilai Sig 0,000 dan $t_{\text {hitung }}=4,794$ sedangkan $t_{\text {tabel }}=1,663$. Karena Sig $<0,05$ dan nilai $t_{\text {hitung }}>t_{\text {tabel }}$ berarti terdapat pengaruh langsung konsep diri $\left(\mathrm{X}_{1}\right)$ terhadap pemahaman konsep matematika $\left(\mathrm{X}_{3}\right)$.

\section{Pengujian Hipotesis 2}

Nilai Sig 0,000 dan $t_{\text {hitung }}=11,831$ sedangkan $t_{\text {tabel }}=1,663$. Karena Sig $<0,05$ dan nilai $t_{\text {hitung }}>t_{\text {tabel }}$ berarti terdapat pengaruh langsung kecemasan siswa $\left(X_{2}\right)$ terhadap pemahaman konsep matematika $\left(\mathrm{X}_{3}\right)$.

\section{Pengujian Hipotesis 3}

Nilai Sig 0,000 dan $t_{\text {hitung }}=9,787$ sedangkan $t_{\text {tabel }}=1,663$. Karena Sig $<0,05$ dan nilai $t_{\text {hitung }}>t_{\text {tabel }}$ berarti terdapat pengaruh langsung konsep diri $\left(X_{1}\right)$ terhadap kecemasan siswa $\left(\mathrm{X}_{2}\right)$. 


\section{Pengujian Hipotesis 4}

Dari perhitungan menggunakan Ms Excel didapatkan $t_{\text {hitung }}(8,016)>t_{\text {tabel }}(1,633)$ yang berarti terdapat pengaruh tidak langsung antara konsep diri $\left(\mathrm{X}_{1}\right)$ terhadap pemahaman konsep matematika $\left(\mathrm{X}_{3}\right)$ melalui kecemasan siswa $\left(\mathrm{X}_{2}\right)$.

\section{Pembahasan}

\section{Pengaruh Langsung Konsep Diri Terhadap Pemahaman Konsep Matematika}

Berdasarkan hasil analisis dapat diketahui persamaan regresi $\widehat{Y}=0,283 \mathrm{X}_{1}+$ $0,699 \mathrm{X}_{2}$. Yang berarti bahwa koefisien regresi konsep diri sebesar 0,283 memberikan pemahaman bahwa setiap penambahan satu satuan atau satu tingkatan konsep diri akan berdampak pada meningkatnya pemahaman konsep matematika sebesar 0,283 satuan.

Hasil penelitian memberikan hasil signifikan, hal ini membuktikan bahwa ada pengaruh positif dan signifikan antara konsep diri terhadap pemahaman konsep matematika, atau dengan kata lain, siswa yang memiliki kepercayaan diri dan persepsi serta cara pandang yang positif tentang dirinya sendiri akan mampu meningkatkan pemahaman konsep matematika. Persepsi dan cara pandang tersebut perlu dibangun dan dikembangkan, baik secara internal maupun eksternal, sehingga sudah seharusnya siswa secara pribadi menghargai seluruh aspek kehidupannya, serta sudah seharusnya juga seluruh elemen di luar diri siswa (termasuk guru, kepala sekolah, orang tua dan masyarakat) memberikan penghargaan dan apresiasi yang optimal sehingga siswa dapat membangun konsep diri yang positif.

Pudjijogyanti dalam Respati (2006:125) mengatakan: "selain keluarga dan teman, konsep diri juga dapat terbentuk dari interaksi guru dan murid saat anak memasuki masa sekolah". Di sekolah anak mulai mengenal dan berinteraksi dengan guru serta memperoleh tugas-tugas baru. Dapat atau tidaknya ia mengerjakan tugas-tugas itu akan memberikan pengaruh pada konsep diri.

Berdasarkan temuan penelitian tersebut maka dapat disimpulkan bahwa siswa yang memiliki kepercayaan diri dan persepsi serta cara pandang yang positif tentang dirinya sendiri akan mampu meningkatkan pemahaman konsep matematika.

Berdasarkan hasil perhitungan di atas, maka hasil penelitian ini sesuai dan sejalan dengan pengajuan hipotesis penelitian yang menyatakan bahwa terdapat pengaruh langsung konsep diri terhadap pemahaman konsep matematika.

\section{Pengaruh Langsung Kecemasan Siswa Terhadap Pemahaman Konsep Matematika}

Berdasarkan hasil analisis dapat diketahui persamaan regresi $\widehat{\mathrm{Y}}=0,283 \mathrm{X}_{1}+$ $0,699 \mathrm{X}_{2}$. Yang berarti bahwa koefisien regresi kecemasan siswa sebesar 0,699 memberikan pemahaman bahwa setiap penambahan satu satuan atau satu tingkatan kecemasan siswa akan berdampak pada meningkatnya pemahaman konsep matematika sebesar 0,283 satuan.

Nawangsari (2001:83), "kecemasan adalah suatu kondisi yang tidak menyenangkan meliputi rasa takut, rasa tegang, khawatir, bingung, tidak suka yang sifatnya subjektif dan timbul karena adanya perasaan tidak aman terhadap bahaya yang diduga akan terjadi". Wicaksono dan Saufi (2013:93) menyatakan bahwa: "salah satu sebab utama kecemasan siswa adalah otoritas guru". Sementara menurut Ashcraft dalam Anita (2014:97) mendefinisikan kecemasan matematika sebagai perasaan ketegangan, cemas atau ketakutan yang mengganggu kinerja matematika. Siswa yang mengalami kecemasan matematika cenderung menghindari situasi dimana mereka harus mempelajari dan mengerjakan matematika. 
Akan tetapi fenomena kecemasan di dunia pelajar sedikit banyak memunculkan reaksi yang berbeda. Ada siswa yang semakin ia cemas maka akhirnya berjuang untuk mengatasi kecemasannya itu dengan cara belajar, yang tujuannya adalah memperoleh hasil yang terbaik. Contoh ketika siswa di beri tugas oleh guru dan tidak ada hukuman jika mendapat nilai jelek maka banyak siswa yang mengerjakan soal tersebut dengan asal beda halnya ketika guru memberikan tugas dimana jika tugas tersebut tidak di kerjakan dan mendapat nilai jelek maka ada hukuman yang di dapat, dengan mengingat ada hukuman para siswa akan mengerjakan tugas tesebut dengan sungguh-sungguh. Hal tersebut di lakukan siswa karena mereka cemas bagaimana jika ia tidak mendapat nilai bagus dan mendapat hukuman. Berdasarkan temuan penelitian tersebut maka dapat disimpulkan bahwa semakin tinggi kecemasan siswa maka semakin tinggi pemahaman konsep matematikanya.

Berdasarkan hasil perhitungan di atas, maka hasil penelitian ini sesuai dan sejalan dengan pengajuan hipotesis penelitian yang menyatakan bahwa terdapat pengaruh langsung kecemasan siswa terhadap pemahaman konsep matematika.

\section{Pengaruh Langsung Konsep Diri Terhadap Kecemasan Siswa}

Berdasarkan hasil analisis dapat diketahui persamaan regresi $\widehat{Y}=0,722 \mathrm{X}_{1}$. Yang berarti bahwa koefisien regresi konsep diri sebesar 0,722 memberikan pemahaman bahwa setiap penambahan satu satuan atau satu tingkatan konsep diri akan berdampak pada meningkatnya kecemasan siswa sebesar 0,722 satuan.

Menurut Nawangsari (2001:83), "kecemasan adalah suatu kondisi yang tidak menyenangkan meliputi rasa takut, rasa tegang, khawatir, bingung, tidak suka yang sifatnya subjektif dan timbul karena adanya perasaan tidak aman terhadap bahaya yang diduga akan terjadi”.

Menurut Montana (2010), remaja yang mengembangkan konsep diri positif akan merasa dirinya berharga sehingga lebih percaya diri dalam menghadapi berbagai keadaan dan masalah. Sebaliknya remaja yang mengembangkan konsep diri negatif, mempunyai kesulitan dalam menerima diri sendiri, sering menolak diri serta sulit bagi dia untuk melakukan penyesuaian diri. Remaja yang mempunyai konsep diri positif akan membantu dalam mengerjakan tugas dan sebaliknya remaja dengan konsep diri negatif akan menghambat dalam menyelesaikan tugasnya.

Dari uraian di atas dikatakan bahwa, kecemasan siswa di pengaruhi oleh konsep diri yang dimiliki siswa. Siswa yang memiliki kepercayaan diri dan persepsi serta cara pandang yang positif tentang dirinya sendiri maka akan mampu mengontrol tingkat kecemasannya. Berdasarkan hasil perhitungan di atas, maka hasil penelitian ini sesuai dan sejalan dengan pengajuan hipotesis penelitian yang menyatakan bahwa terdapat pengaruh langsung konsep diri terhadap kecemasan siswa.

\section{Pengaruh Tidak Langsung Konsep Diri Terhadap Pemahaman Konsep Matematika Melalui Kecemasan Siswa}

Berdasarkan hasil perhitungan di peroleh $t_{\text {hitung }}(0,729)<t_{\text {tabel }}(1,633)$, hal ini menunjukan bahwa tidak terdapt pengaruh tidak langsung konsep diri terhadap pemahaman konsep matematika melalui kecemasan siswa.

Berdasarkan temuan yang ada dapat disimpulkan bahwa pemahaman konsep matematika merupakan variabel yang sangat rentan terhadap perubahan, pemahaman konsep matematika tidak hanya dipengaruhi oleh faktor ekstern siswa tetapi juga dipengaruhi oleh faktor intern. Usaha meningkatkan pemahaman konsep matematika hanya mungkin dilakukan dengan membangun gerakan secara bersama-sama antara faktor intern dan faktor ekstern. Salah satu faktor intern yang cukup berperan dalam 
peningkatan pemahaman konsep matematika siswa adalah konsep diri dan kecemasan siswa.

Pudjijogyanti dalam Respati (2006:125) mengatakan: "selain keluarga dan teman, konsep diri juga dapat terbentuk dari interaksi guru dan murid saat anak memasuki masa sekolah". Di sekolah anak mulai mengenal dan berinteraksi dengan guru serta memperoleh tugas-tugas baru. Dapat atau tidaknya ia mengerjakan tugas-tugas itu akan memberikan pengaruh pada konsep diri.

Nawangsari (2001:83), "kecemasan adalah suatu kondisi yang tidak menyenangkan meliputi rasa takut, rasa tegang, khawatir, bingung, tidak suka yang sifatnya subjektif dan timbul karena adanya perasaan tidak aman terhadap bahaya yang diduga akan terjadi". Sementara menurut Ashcraft dalam Anita (2014:97) mendefinisikan kecemasan matematika sebagai perasaan ketegangan, cemas atau ketakutan yang mengganggu kinerja matematika. Siswa yang mengalami kecemasan matematika cenderung menghindari situasi dimana mereka harus mempelajari dan mengerjakan matematika.

Akan tetapi fenomena kecemasan di dunia pelajar sedikit banyak memunculkan reaksi yang berbeda. Ada siswa yang cemas dan akhirnya berjuang untuk mengatasi kecemasannya itu dengan cara belajar, yang tujuannya adalah memperoleh hasil yang terbaik yaitu meningkatnya pemahamannya terhadap pemahaman konsep matematika. Dan penelitian ini berhasil menemukan bahwa kecemasan belajar yang berlebihan berpengaruh positif terhadap pemahaman siswa dalam belajar. Siswa yang mampu mengendalikan kecemasannya akan menjadi lebih semangat dalam belajar karena siswa tersebut khawatir jika hasil belajarnya tidak baik artinya kecemasan berpengaruh positif. Sedangkan siswa yang tidak mampu mengendalikan kecemasan dalam dirinya dapat membuat siswa tersebut semakin cemas sehingga tersebut putus asa.

Dengan demikian perlu adanya bimbingan guru dan orang tua agar siswa dapat melatih kepercayaan diri dan persepsi serta cara pandang yang positif tentang dirinya sendiri, karena dengan memiliki kepercayaan diri yang positif tentang dirinya akan mampu mengontrol tingkat kecemasannya, sehingga siswa yang mampu mengontrol tingkat kecemasannya akan berhasil dalam pemahaman konsep matematika.

\section{PENUTUP}

\section{Simpulan}

1. Terdapat pengaruh langsung yang signifikan konsep diri $\left(X_{1}\right)$ terhadap pemahaman konsep matematika $\left(X_{3}\right)$ dengan berdasarkan Sig 0,000 dan $t_{\text {hitung }}=4,794$ sedangkan $t_{\text {tabel }}=1,663$. Karena nilai Sig $<0,05$ dan $t_{\text {hitung }}>t_{\text {tabel }}$ yang berarti terdapat pengaruh langsung yang signifikan konsep diri $\left(\mathrm{X}_{1}\right)$ terhadap pemahaman konsep matematika $\left(\mathrm{X}_{3}\right)$.

2. Terdapat pengaruh langsung yang signifikan kecemasan siswa $\left(\mathrm{X}_{2}\right)$ terhadap pemahaman konsep matematika $\left(\mathrm{X}_{3}\right)$ dengan berdasarkan Sig 0,000 dan $\mathrm{t}_{\text {hitung }}=$ 11,831 sedangkan $t_{\text {tabel }}=1,663$. Karena nilai Sig $<0,05$ dan $t_{\text {hitung }}>t_{\text {tabel }}$ yang berarti terdapat pengaruh langsung yang signifikan kecemasan siswa $\left(X_{2}\right)$ terhadap pemahaman konsep matematika $\left(\mathrm{X}_{3}\right)$.

3. Terdapat pengaruh langsung yang signifikan konsep diri $\left(\mathrm{X}_{1}\right)$ dengan kecemasan siswa $\left(X_{2}\right)$ dengan berdasarkan nilai Sig 0,000 dan $t_{\text {hitung }}=9,787$ sedangkan $t_{\text {tabel }}=$ 1,663. Karena $\operatorname{Sig}<0,05$ dan nilai $t_{\text {hitung }}>t_{\text {tabel }}$ yang berarti terdapat pengaruh langsung yang signifikan konsep diri $\left(\mathrm{X}_{1}\right)$ dengan kecemasan siswa $\left(\mathrm{X}_{2}\right)$.

4. Terdapat pengaruh tidak langsung yang signifikan konsep diri $\left(\mathrm{X}_{1}\right)$ terhadap pemahaman konsep matematika $\left(X_{3}\right)$ melalui kecemasan siswa $\left(X_{2}\right)$ dengan berdasarkan $t_{\text {hitung }}(8,016)>t_{\text {tabel }}(1,633)$ yang berarti terdapat pengaruh tidak 
langsung yang signifikan konsep diri terhadap pemahaman konsep matematika melalui kecemasan siswa.

Saran berikut:

Berdasarkan hasil penelitian dan simpulan, dikemukan beberapa saran sebagai

1. Siswa sebagai individu harus berusaha menghargai hidup dan kehidupannya, termasuk potensi yang dimilikinya sehingga dapat memiliki kepercayaan diri dalam menghadapi tantangan ke depan. Guru, kepala sekolah, orang tua dan masyarakat sebagai orang terdekat siswa juga harus berusaha memberikan penghargaan yang cukup kepada siswa dalam rangka peningkatan konsep diri siswa yang dampaknya akan meningkatkan pemahaman konsep matematika siswa.

2. Guru sebagai unsur terdepan dalam proses pembelajaran harus memperhatikan tingkat kecemasan siswa. Dengan kata lain, guru harus dapat mengarahkan siswa agar mampu mengontrol tingkat kecemasannya, sehingga dampaknya dapat meningkatkan pemahaman konsep matematika siswa.

3. Seluruh elemen pendidikan juga dapat mengontrol tingkat kecemasan siswa, artinya siswa tidak boleh diberikan situasi atau keadaan yang dapat meningkatkan kecemasannya, karena dampaknya akan menurunkan pemahaman konsep matematika.

4. Siswa dan guru harus mampu mengembangkan suatu suasana pendidikan yang kondusif dimana siswa mampu meningkatkan konsep dirinya yang pada akhirnya mampu mengontrol kecemasannya sehingga berdampak positif terhadap pemahaman konsep matematika.

\section{DAFTAR PUSTAKA}

Anita, Ika Wahyu. 2014. Pengaruh kecemasan matematika (mathematics anxiety) terhadap kemampuan koneksi matematika siswa smp. Jurnal Ilmiah Program Studi Matematika STKIP Siliwangi Bandung, 3 (1): 125-132.

Chaplin, J.P. 2001. Kamus Lengkap Psikologi. Jakarta: PT. Raja Grafindo Persada. Penerjemah: Dr. Kartini Kartono.

Dimyati dan Mudjiono. 2009. Belajar dan Pembelajaran. Jakarta: Rineka Cipta.

Hamalik, O. Perencanaan Pangajaran Berdasarkan Pendekatan Sistem. Jakarta: Bumi Aksara, 2008.

Heruman. 2010. Model Pembelajaran Matematika di Sekolah Dasar. Bandung: PT. Remaja Rosda Karya.

Kesumawati, Nila. 2008. Pemahaman Konsep Matematika dalam Pembelajaran Matematika. Makalah diseminarkan dalam Seminar Nasional Matematika dan Pendidikan Matematika di jurusan Pendidikan Matematika Universitas PGRI Palembang, Palembang, 2008.

Montana. 2010. Positive \& Negative Self Concept, www.montana.edu(www4h/Self. Html-8k)

Mulyana, D. 2000. Ilmu Komunikasi, Pengantar. Remaja Rosadakarya, Bandung.

Nawangsari, N.A.F. 2001. Pengaruh self-efficacy dan expectancy-value terhadap kecemasan menghadapi pelajaran matematika. Jurnal Psikologi Pendidikan: Insan Media Psikologi, 3 (2): 75-88.

Respati, Siwi Winanti, dkk. 2006. Perbedaan konsep diri antara remaja akhir yang mempersepsi pola asuh orang tua authorian, permissive dan authoritative. Jurnal Psikologi, 4 (2): 119-135. 
Ruseffendi, E. T. 2006. Pengantar kepada Membantu Guru Mengembangkan Kompetensinya dalam Pengajaran Matematika untuk Meningkatkan CBSA. (Edisi Revisi). Bandung: Tarsito.

Slameto. 2010. Belajar dan Faktor-faktor yang Mempengaruhinya. Jakarta: Rineka Cipta.

Tanamal, Debby. 2004. Tinjauan Teori dan Evaluasi Dalam Pembentukan KarakterPeserta Didik. Jurnal Character Building I, Universitas Bina Nusantara, Jakarta.

U.S., Supardi. Aplikasi Statistika Dalam Penelitian. Jakarta: PT Ufuk Publishing House, 2012.

Wicaksono, Arief dan Saufi, M. 2013. Mengelola Kecemasan Siswa Dalam Pembelajaran Matematika. Makalah diseminarkan dalam Seminar Nasional Matematika dan Pendidikan Matematika di jurusan Pendidikan Matematika FMIPA UNY, Yogyakarta, 19 November 2013. 